\title{
ASSESSMENT OF DERMAL PESTICIDE EXPOSURE INSIDE GREENHOUSES USING FLUORESCENT TRACER METHOD
}

\author{
S. M. Younis ${ }^{1}$, K. M. Abdelbary ${ }^{2}$ and M. S. M. Metawe $^{3}$
}

\section{ABSTRACT}

The main object of the search work is to assess the dermal pesticide exposure inside greenhouses during its application and to compare pesticide pollution resulted from handgun sprayer with its values of a vertical boom sprayer prototype. Fluorescent tracer, is semi-quantitative dermal exposure assessment method based on visual observations of fluorescence images, had been used to demonstrate the extent to which dermal exposure can occur under inadequate protective conditions. 22 body segments (> 90\% of the total body surface area) scored for all workers. Prototype is superior to handgun sprayer, contaminated area ratio of glasses was $0.28 \%$ - no pollution for the mask versus $8.11 \%$ and $9.15 \%$ respectively. Trunk, buttock, chest and shoulder contaminated area with handgun sprayer were 1.75, 1.60, 0.60 and $6.69 \%$ (front view) and were $1.79,9.51,0.73$ and 0.00 at back view versus no pollution (0.00 $\%)$ in all previous cases with vertical boom sprayer prototype. No pollution in any area of worker's arms compared to polluted area ranged between 0.00 and $8.17 \%$ for handgun sprayer. Contaminated area of gloves (5\% of total body area) ranged between 0.00 and $0.92 \%$ for vertical spray boom prototype versus $11.72 \%$ - $19.50 \%$ for handgun sprayer. Worker's legs exposed to some pollution (0.42\% and 0.82\%) against more detected exposure extended to $13.36 \%$ for handgun sprayer. Regrettably, workers did not wear safety boots, though no data for feet area, which form about $7 \%$ of total body area, was taken. Tested prototype maintained more working safety conditions when compared to handgun sprayer.

Keywords: Pesticides, Dermal exposure, assessment, greenhouse, safety, environment, Fluorescent tracer, spray deposition,, inhalation, protective equipment.

\footnotetext{
${ }^{1}$ Prof., Agric. Eng. Dept., Fac. of Agric., Cairo Univ., Giza, Egypt.

${ }^{2}$ Assist. Prof., Agric. Eng. Dept., Fac. of Agric., Cairo Univ., Giza, Egypt.

${ }^{3}$ M. Sc. Student, Agric. Eng. Dept., Fac. of Agric., Cairo Univ., Giza, Egypt.
} 
As the recorded percentages of contaminated areas were all the way, less than the corresponding contaminated areas when using handgun sprayer. The overall average percentage of body exposure for VBS was $1.5 \%$ against $5.8 \%$ for handgun sprayer.

\section{INTRODUCTION}

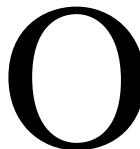

ccupational exposure evaluation of workers to pesticides is an integral part of the risk assessment for product safety and regulatory purposes. Pesticides exposure during greenhouse application occurred directly during treatments or indirectly from contact with treated plants and surfaces and during re-entry activities (walking through pesticide mist) (Giannandrea et al., 2008, Braekman and Sonck, 2008). Furthermore, it can be occurred by dermal (through skin), ocular (through eyes), oral ingestion and from inhalation. Dermal exposure is the most common, accounting for $97 \%$ of all reported exposures (Fishel, 2011). Personal protective equipment (PPE) is equipment worn to minimize exposure to a variety of hazards. Examples of PPE include such items as gloves, foot and eye protection, protective hearing devices (earplugs, muffs) hard hats, respirators and full body suits (OSHA, 2003, Evans et al., 2001).

Many research works reported that (Durham and Wolfe, 1962, Fenske, 1993, Archibald et al., 1995, Cherrie et al., 2000, Vidal et al., 2002, Fenske et al., 2005, Wendel de Joode et al., 2005, MacIntyre-Allen et al., 2007, Schleier, et al., 2010 and Fritz et al., 2011) when the skin is the primary contributor to absorbed dose, dermal exposure measurements and biological monitoring play complementary roles in defining occupational exposures.

Chester, (1993) reviewed exposure-monitoring methods for the measurement of exposure to, and absorption of, pesticides by workers. He reported that biological monitoring was recommended as the most precise means of estimating the absorbed dose of a pesticide, particularly if supported by human metabolism and pharmacokinetic data.

Chester, (1993) added, also, that 'whole-body' sampling method, which involves the use of clothing representing that which workers normally wear under the prevailing conditions, was recommended for the measurement of dermal exposure. Whole body technique used by many 
researches, Bozdogan and Bozdogan, 2009, Nuyttens et al., 2009. Soutar et al., 2000 and Nuyttens et al., 2009 used patches and whole body sampling for the assessments of dermal exposure, Soutar et al., (2000) reported that one of the problems associated with dermal sampling was that different methods often produced different results due to differences in the principals involved in sample collection. Finally, personal air sampling method is recommended for the measurement of inhalation exposure, to collect the 'inspirable' fraction (and/or, where necessary, vapor component) of pesticide. With these air-sampling methods in hand and the ability to quantify exposures, establishing acceptable concentrations based on toxicological data and empirical workplace exposure outcomes was a natural progression (Boeniger, 2003).

Whereas, (Fenske, 1993), divided sampling methods into three categories (surrogate skin; chemical removal and fluorescent tracers). His study illustrated that surface sampling represented a supplementary approach, providing an estimate of dermal exposure potential. Surrogate skin techniques, (placing a chemical collection medium on the skin), have had a validity rested on the ability of the sampling medium to capture and retain chemicals in a manner similar to skin. Removal techniques included skin washing and wiping but this measure illustrated what can be removed from the skin, not exposure.

Fluorescent tracer techniques exploited the visual properties of fluorescent compounds, and combined with imaging to make quantification of dermal exposure patterns possible. Tracer materials, such as oil and water-soluble fluorescent dyes, can be mixed into spray solutions in small amounts with minimal impact on the solution physical properties and atomization characteristics of the nozzle or spray system (Schleier, et al., 2010 and Fritz et al., 2011).

Archibald et al., (1995) measured pesticides exposure in greenhouse applicators using the video imaging technique to assess exposure along with dermal patches, air monitoring and biological assessment techniques. They evaluated pesticides exposure of five males during high and low-volume application methods. They stated that failure to use precautionary handling methods when using low-volume applications 
resulted in the highest level of dermal tracer deposition. Their results demonstrated, also, non-uniform deposition of tracer/pesticide mixtures on various body regions.

Cherrie et al., (2000) mentioned that fluorescent tracers provide a way of simultaneously assessing the mass of a contaminant hazardous substance on the surface of the skin of a worker and the area of skin exposed. These parameters, along with the duration of exposure and the estimated contaminant concentration in the skin contamination layer, can be used to calculate the likely uptake through the skin. Repeated assessment of the mass of tracer on a surface within a room or on the surface of the skin can also allow the net transfer of contaminant to that compartment to be estimated. Qualitative evaluation of transfer processes using fluorescent tracers can help identify important secondary sources of exposure.

Measuring soil deposits from pesticide applications are somewhat limited. As an alternative to using pesticide residue analysis, a simple tracer technique has been developed using the fluorescent dye Tinopal CBS-X to measure deposits directly on the soil (Barber and Parkin, 2003). They added, because there are soil tracer interactions with Tinopal CBS-X, the technique allows for variations in organic matter content by making use of a sorption isotherm as a calibration line.

Machera et al., (2002) and (2003) measured the potential dermal and inhalation exposure of the operator, following simulation of insecticide application with the dye tracer Sunset Yellow in greenhouse cucumbers and tomatoes. They used the whole body technique for monitoring of operator exposure and measured the potential inhalation exposure with a personal air sampler equipped with a glass fiber filter.

Aragón et al., (2006) adapted a semi-quantitative dermal exposure assessment method based on visual observations of fluorescence images to Nicaraguan working conditions on thirty-two farmers applied chlorpyrifos and methamidophos marked with Tinopal CBS-X® ${ }^{\circledR}$ and evaluated its performance. They observed skin fluorescent depositions with a portable UV lamp in a foldaway darkened room. They found that contaminated body area ranged between 1 and $66 \%$ and fluorescent images reflected work practices and contamination mechanisms. 
MacIntyre-Allen et al., (2007) examined track sprayer and field sprayer trials to assess the effect of different nozzles, surfactants and carrier volumes on product delivery to the inner leaves of onion plants using a fluorescent tracer. They used Tinopal CBS-X (Ciba-Geigy, Greensboro, NC) (tracer), a water-soluble fluorescent tracer dye, to visualize spray depositions, in all trials. They reported, also, that Tinopal fluoresces brilliant blue-violet with an absorption maximum of $349 \mathrm{~nm}$ and an emission maximum of $440 \mathrm{~nm}$ is commonly used in spray deposition studies. Their work demonstrated great variation for tracer detected in the target treatment area depending on the nozzle, the presence and type of surfactant and the carrier volume.

The main object of recent search work is to assess the dermal pesticide exposure inside greenhouses during its application; specified aim is to compare pesticide pollution resulted from handgun sprayer with its values of vertical spray boom prototype.

\section{MATERIALS AND METHODS}

\section{a- Prototype}

Experimental vertical spray boom prototype with $50 \mathrm{rpm}$, single phase electrical motor, $1 \mathrm{~km} / \mathrm{h}$ maximum speed and 8 Copper nozzles with spraying discharge of $60 \mathrm{~L} / \mathrm{m}$, maximum dynamic head $40 \mathrm{~m}$ and maximum suction of $9 \mathrm{~m}$ was manufactured and tested. Vertical spray boom was of $150 \mathrm{~cm}$ height and nozzle spacing was $40 \mathrm{~cm}$ under operating pressure of 2 bar. Handgun sprayer (Manual Sprayer, Knapsack ${ }^{\circledR}$, Model: GF-04-01, 20L Capacity, Normal Pressure of: 0.1$0.2 \mathrm{mPa}$, with dimension of: $41 \times 20 \times 52 \mathrm{~cm}$ ) was used to be compared with the vertical spray boom. Water, MALASON/CHEMINOVA $57 \%$ and Lambada Cyhalothrine 5\% were used as spray liquids.

b- Greenhouse

Experimental greenhouses, with $9 \mathrm{~m}$ width, $30 \mathrm{~m}$ length (actual length of $27.5 \mathrm{~m}$ and $2.5 \mathrm{~m}$ for services and storage) and height of $2.5 \mathrm{~m}$, at greenhouse side and $3.75 \mathrm{~m}$ at its center represented test area, Fig. (1). It used for ornamental plants breeding (internal and external ornamentals) (maximum height of $180 \mathrm{~cm}$ and minimum heights of $120 \mathrm{~cm}$ ) and was divided into basins, 4 meters wide, the main greenhouse axis width was 1 $\mathrm{m}$. Cooling system of two exhausting fans with $1 \mathrm{~m}$ width and $1 \mathrm{~m}$ 
height, cooling pads with dimensions of 1.5 high and 2.5 wide were used to control greenhouse internal environmental conditions. Even span trussed roof was used with galvanized steel structural material, green fiberglass (forced rain plastic (FRP) with $1 \mathrm{~mm}$ thickness) was used as a cover material.

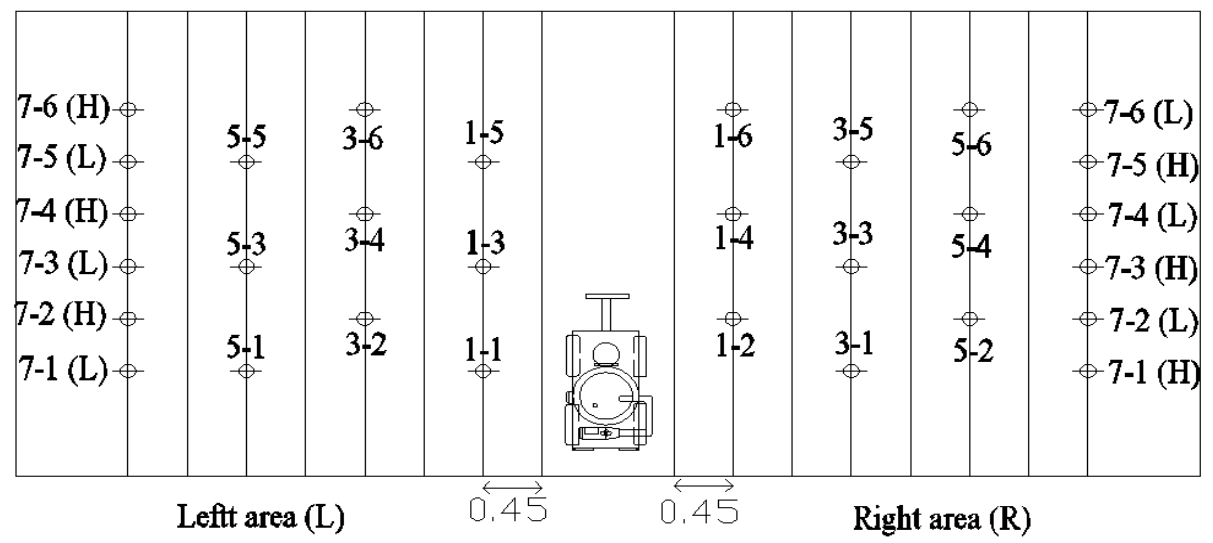

Fig. (1). Field experiments layout.

Ten varieties of ornamental plants included (dracaena fragrans, dracaena marginata,dracaena deremensis,dracaena tricolor, yucca aloifolia, Yucca variegate, Giant Yucca ,Yucca filamentosa , Syngonium Stick, Pothos Plant stick). Water receiving papers were fixed on the plants leaves to examine distribution of droplets count and pesticide solution coverage percent over plant leaf area.

\section{c- Florescent}

For inspect and examine fluorescent colors in a dark rooms, $30 \mathrm{~cm}$, hand held florescent lamp MINA ${ }^{\circledR}$ T5 Blacklight Blue (F8WT5/BLB, 8W56V- 0.145A and 50-60 Hz) was used, Fig. (2) . Lamp was fixed in high quality, electronic energy saving, white NEOLUX® ${ }^{\circledR}$ T5 fluorescent stand. The lamp efficiently emitted near ultraviolet radiation at $315 \mathrm{~nm}-$ $400 \mathrm{~nm}$ with strong photochemical and fluorescent effects. Its special deep blue filter glass absorbs all visible radiations and transmits longwave (near) (UV-A) ultraviolet rays only. Shape, electrical characteristics and lighting circuits are similar to general fluorescent lamps. 


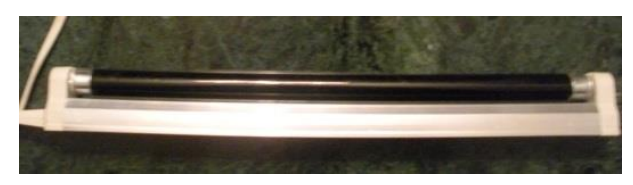

(a). Blacklight Blue lamp "off” in light.

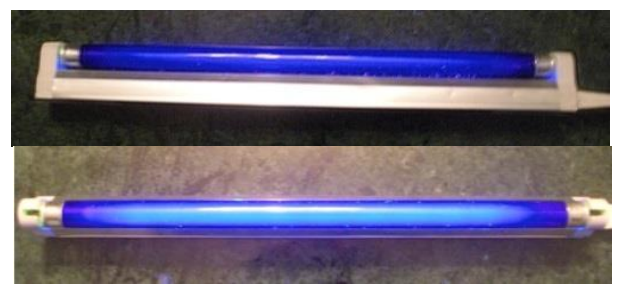

(b). Blacklight Blue lamp "on" in light.

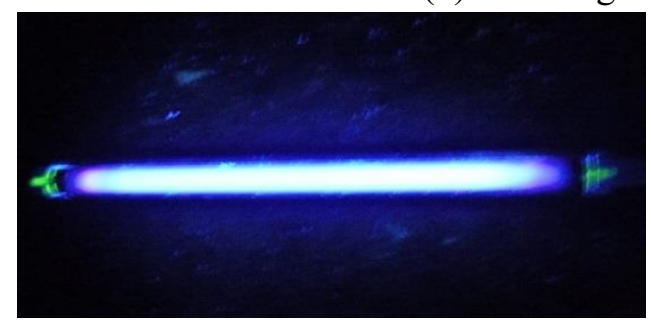

(c). Blacklight Blue lamp "on" in dark.

Fig.(2). $30 \mathrm{~cm}$ florescent lamp (F8WT5/BLB) with white NEOLUX® T5 fluorescent stand.

d- Tracer material

Maries $\AA$ Acrylic Colors, that is a fine quality acrylic paint with buttery consistency, was used as a tracer material, Fig. (3). Two colors, (373; florescent pink and 272; florescent lemon yellow) were used and the tracer was placed into the tank of the prototype at a rate of $0.25 \mathrm{~kg} / 40 \mathrm{~L}$ of water. Workers applied pesticide as usual, then after finishing the application, fluorescent tracer will mark hazardous substance location deposits on the coverall. Whole coverall is exposed to long-wave ultraviolet light. A room and a digital camera were used to record images of the exposed parts of the body.
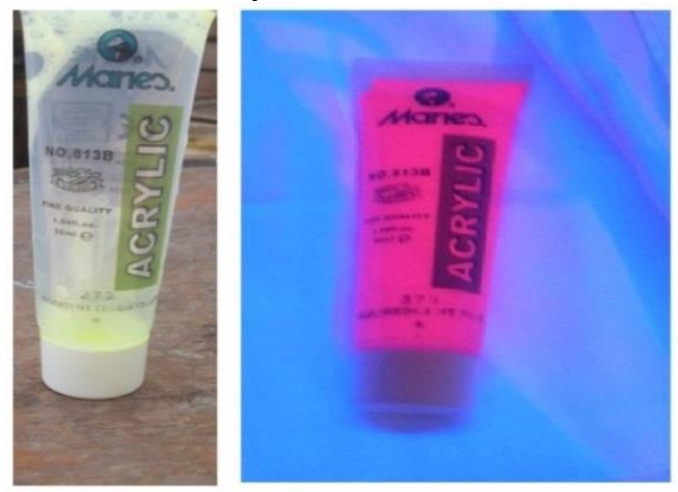

Fig. (3). Maries ${ }^{\circledR}$ Acrylic Colors tracer agent. 
e- Body surface segments

To evaluate the whole boy surface, worker's body was divided, basically, into three parts included: (1) head , (2) body right side and (3) body left side. Each body's part was subsequently sub-divided into front and back except buttock area. Head part was divided at front view into 4 sections (glasses, mask, face right side and face left side) the back of the head was divided into just two sections (upper and lower). Whereas, both body sides were distributed to the following sections: shoulder, upper chest, lower chest, upper arm, forearm, hand (glove), thigh, shin and boot. These parts produced 22 body segments at front view and 20 segments at back view as illustrated in Fig.(4) Every worker wore chemical resistant coverall, chemical splash goggles or a full-face respirator, unlined and chemical resistant (neoprene) gloves. Unfortunately, chemical-resistant boots were not available for recent workers.

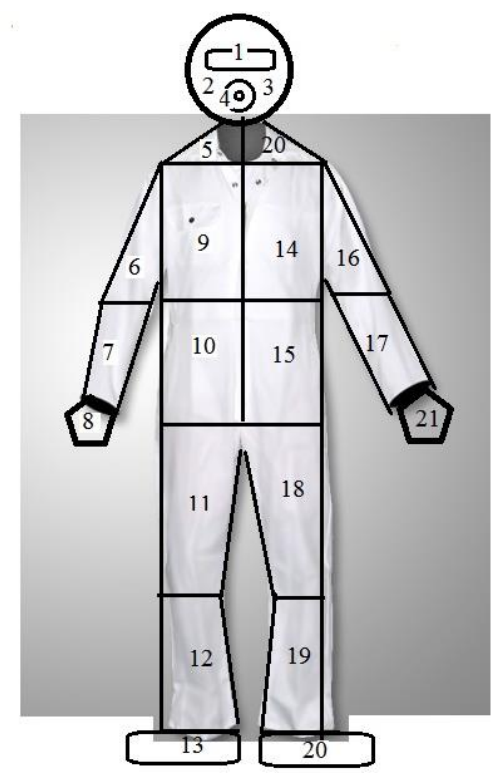

Front view

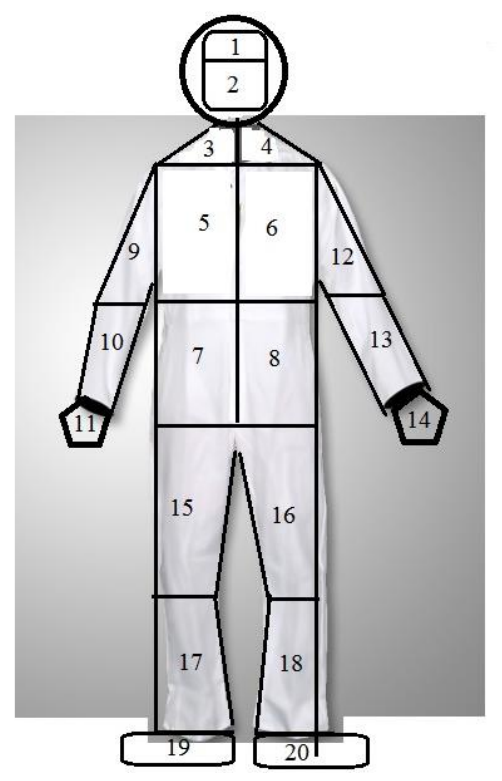

Back view

Fig. (4). Whole coverall surface segments distribution.

\section{RESULTS AND DISCUSSION}

The quantitatively examined fluorescent tracer technique by means of a UV lamp with photo imaging to estimate exposure of the entire body surface gave many results. Whole body surface resulted in 22 body segments scored for all workers, accounting for more than $90 \%$ of the total body surface area. Body surface part, proportion of total body 
surface, body segment measured area contaminated body area and contaminated area covering ratio percentage (as the percentage of contaminated skin in relation to total body surface) for both front and back views are illustrated in Table (1) and table (2) respectively.

Table (1). 22 recorded data from Front View for both prototype and handgun sprayer.

\begin{tabular}{|c|c|c|c|c|c|c|}
\hline \multirow{2}{*}{$\begin{array}{l}\text { Coverall } \\
\text { surface } \\
\text { part }\end{array}$} & \multirow{2}{*}{$\begin{array}{c}\text { Body } \\
\text { segment }\end{array}$} & \multirow{2}{*}{$\begin{array}{c}* \text { Proportion } \\
\text { of total } \\
\text { body } \\
\text { surface } \%\end{array}$} & \multirow{2}{*}{$\begin{array}{c}\text { Coverall } \\
\text { segment } \\
\text { measured } \\
\text { area } \\
\left(\mathrm{cm}^{2}\right)\end{array}$} & \multirow{2}{*}{$\begin{array}{c}\text { Calculated } \\
\text { Proportion } \\
\text { of total } \\
\text { body } \\
\text { surface } \%\end{array}$} & \multicolumn{2}{|c|}{$\begin{array}{c}\text { Contaminated } \\
\text { Coverall Area Ratio } \\
(\text { CCAR }) \%\end{array}$} \\
\hline & & & & & Prototype & $\begin{array}{c}\text { Handgun } \\
\text { sprayer }\end{array}$ \\
\hline \multirow{4}{*}{ Head } & Glasses & \multirow{4}{*}{9} & 172 & \multirow{4}{*}{7.80} & 0.28 & 8.11 \\
\hline & Mask & & 61.5 & & 0.00 & 9.15 \\
\hline & $\begin{array}{l}\text { Right } \\
\text { side }\end{array}$ & & 345 & & 0.00 & 1.50 \\
\hline & Left side & & 345 & & 0.00 & 1.23 \\
\hline \multirow{9}{*}{$\begin{array}{l}\text { Right } \\
\text { side }\end{array}$} & Shoulder & \multirow{3}{*}{16.50} & & \multirow{3}{*}{12.80} & & \\
\hline & $\begin{array}{l}\text { Upper } \\
\text { chest }\end{array}$ & & 850 & & 0.00 & 1.75 \\
\hline & $\begin{array}{c}\text { Lower } \\
\text { chest }\end{array}$ & & 660 & & 0.00 & 1.60 \\
\hline & $\begin{array}{c}\text { Upper } \\
\text { arm }\end{array}$ & 4 & 456 & 3.80 & 0.00 & 3.27 \\
\hline & Forearm & 3 & 492 & 4.17 & 0.00 & 1.30 \\
\hline & Glove & 2.5 & 224.5 & 1.90 & 0.00 & 19.50 \\
\hline & Thigh & 9.5 & 1505 & 12.76 & 0.00 & 0.82 \\
\hline & Shin & 7 & 1245 & 10.56 & 0.00 & 7.94 \\
\hline & Boot & 3.5 & -- & -- & -- & --- \\
\hline \multirow{8}{*}{$\begin{array}{l}\text { Left } \\
\text { side }\end{array}$} & $\begin{array}{c}\text { Shoulder } \\
\begin{array}{c}\text { Upper } \\
\text { chest }\end{array} \\
\end{array}$ & \multirow[t]{2}{*}{16.50} & 850 & \multirow[t]{2}{*}{12.80} & 0.00 & 0.60 \\
\hline & $\begin{array}{c}\text { Lower } \\
\text { chest }\end{array}$ & & 660 & & 0.00 & 6.69 \\
\hline & $\begin{array}{l}\text { Upper } \\
\text { arm }\end{array}$ & 4 & 456 & 3.80 & 0.00 & 0.00 \\
\hline & Forearm & 3 & 492 & 4.17 & 0.00 & 8.17 \\
\hline & Glove & 2.5 & 224.5 & 1.90 & 0.00 & 14.45 \\
\hline & Thigh & 9.5 & 1505 & 12.76 & 0.00 & 1.45 \\
\hline & Shin & 7 & 1245 & 10.56 & 0.42 & 13.36 \\
\hline & Boot & 3.5 & -- & -- & -- & -- \\
\hline Total & 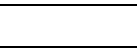 & 100 & 11788.5 & 99.78 & & \\
\hline
\end{tabular}

Fig. (5) shows the visual comparison between glasses and mask for both prototype and handgun sprayer. Contaminated coverall area ratio (CCAR) of glasses was $0.28 \%$ versus $8.11 \%$ and was no pollution in the 
case of prototype against $9.15 \%$ in handgun sprayer case, for the mask. Therefore, it can be said that glasses and musk were, almost free of pesticide pollution taking into consideration that CCAR for right and left side of worker face were $0.00 \%$ using of prototype.

Table (2). 20 recorded data from Back View for both prototype and handgun sprayer.

\begin{tabular}{|c|c|c|c|c|c|c|}
\hline \multirow{2}{*}{$\begin{array}{l}\text { Coverall } \\
\text { surface } \\
\text { part }\end{array}$} & \multirow{2}{*}{$\begin{array}{c}\text { Body } \\
\text { segment }\end{array}$} & \multirow{2}{*}{$\begin{array}{l}\text { *Proportion } \\
\text { of total } \\
\text { body } \\
\text { surface } \%\end{array}$} & \multirow{2}{*}{$\begin{array}{c}\text { Coverall } \\
\text { segment } \\
\text { measured } \\
\text { area } \\
\left(\mathrm{cm}^{2}\right) \\
\end{array}$} & \multirow{2}{*}{$\begin{array}{c}\text { Calculated } \\
\text { Proportion } \\
\text { of total } \\
\text { body } \\
\text { surface \% }\end{array}$} & \multicolumn{2}{|c|}{$\begin{array}{c}\text { Contaminated } \\
\text { Coverall Area Ratio } \\
\text { (CCAR) } \%\end{array}$} \\
\hline & & & & & Prototype & $\begin{array}{c}\text { Handgun } \\
\text { sprayer }\end{array}$ \\
\hline \multirow{2}{*}{ Head } & Upper & \multirow{2}{*}{9} & 398 & \multirow{2}{*}{6.85} & 0.00 & 3.98 \\
\hline & Lower & & 410 & & 0.00 & 1.39 \\
\hline \multirow{9}{*}{$\begin{array}{l}\text { Right } \\
\text { side }\end{array}$} & Shoulder & \multirow{3}{*}{16.50} & & \multirow{3}{*}{12.80} & & \\
\hline & $\begin{array}{l}\text { Upper } \\
\text { chest }\end{array}$ & & 850 & & 0.00 & 1.79 \\
\hline & $\begin{array}{c}\text { Lower } \\
\text { chest }\end{array}$ & & 660 & & 0.00 & 9.51 \\
\hline & $\begin{array}{l}\text { Upper } \\
\text { arm }\end{array}$ & 4 & 456 & 3.80 & 0.00 & 0.79 \\
\hline & Forearm & 3 & 492 & 4.17 & 0.00 & 0.92 \\
\hline & $\begin{array}{l}\text { Glove } \\
\text { (palm) }\end{array}$ & 2.5 & 224.5 & 1.90 & 0.51 & 13.00 \\
\hline & Thigh & 9.5 & 1505 & 12.76 & 0.00 & 7.89 \\
\hline & Shin & 7 & 1245 & 10.56 & 0.00 & 5.88 \\
\hline & Boot & 3.5 & -- & -- & -- & --- \\
\hline \multirow{9}{*}{$\begin{array}{l}\text { Left } \\
\text { side }\end{array}$} & Shoulder & \multirow{3}{*}{16.50} & & \multirow{3}{*}{12.80} & \multirow[b]{2}{*}{0.00} & \multirow[b]{2}{*}{0.73} \\
\hline & $\begin{array}{l}\text { Upper } \\
\text { chest }\end{array}$ & & 850 & & & \\
\hline & $\begin{array}{c}\text { Lower } \\
\text { chest }\end{array}$ & & 660 & & 0.00 & 0.00 \\
\hline & $\begin{array}{l}\text { Upper } \\
\text { arm }\end{array}$ & 4 & 456 & 3.80 & 0.00 & 0.29 \\
\hline & Forearm & 3 & 492 & 4.17 & 0.00 & 3.40 \\
\hline & $\begin{array}{l}\text { Glove } \\
\text { (palm) }\end{array}$ & 2.5 & 224.5 & 1.90 & 0.92 & 11.72 \\
\hline & Thigh & 9.5 & 1505 & 12.76 & 0.00 & 4.96 \\
\hline & Shin & 7 & 1245 & 10.56 & 0.82 & 1.71 \\
\hline & Boot & 3.5 & -- & -- & -- & -- \\
\hline Total & & 100 & 11788.5 & 98.83 & & \\
\hline
\end{tabular}



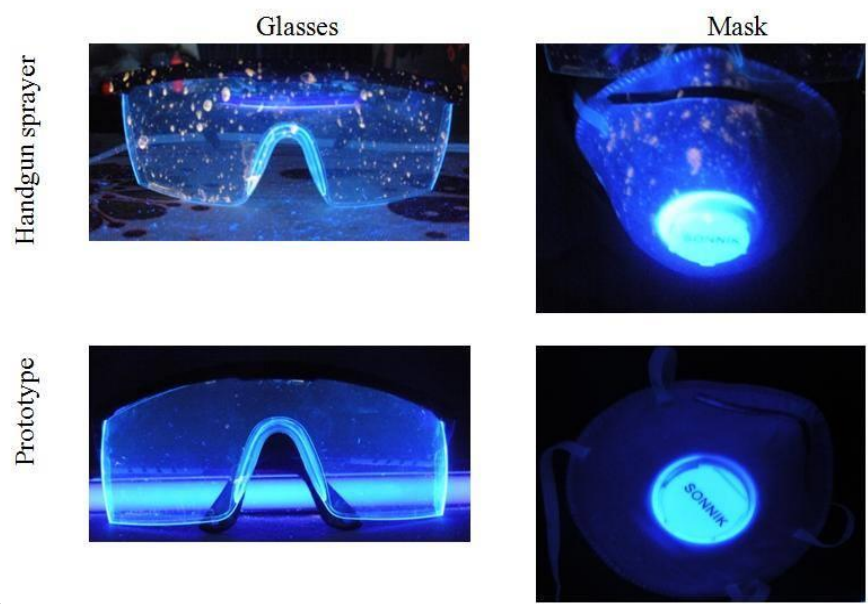

Fig. (5). Comparison between glasses and mask for both prototype and handgun sprayer.

Fig. (6) shows contaminated coverall area of trunk, buttock from front and back view for both prototype and handgun sprayer. Actually, buttock area was merged to back side of trunk, and chest was divided into three section Shoulder, upper chest and lower chest. Shoulder and upper chest were merged, also, in one component. Contaminated coverall area were $1.75,1.60,0.60$ and $6.69 \%$ for right and left side (front view) of handgun sprayer application and were $1.79,9.51,0.73$ and 0.00 at back view versus no pollution $(0.00 \%)$ in all the previous segments with prototype.

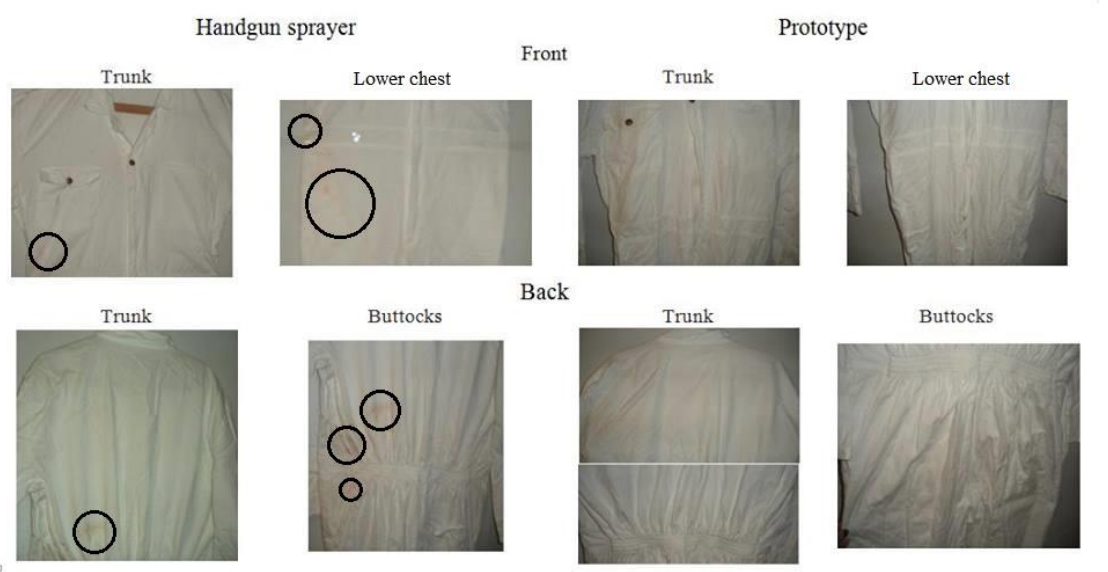

Fig. (6). Contaminated coverall area of trunk, buttock from front and back view for both prototype and handgun sprayer. 
Fig. (7) presents contaminated coverall area of right and left (upper and lower) arm for both handgun sprayer and prototype. Obviously, prototype is still superior to handgun sprayer by no pollution in any area of worker coverall's arm compared to polluted area ranged between 0.00 and $8.17 \%$.

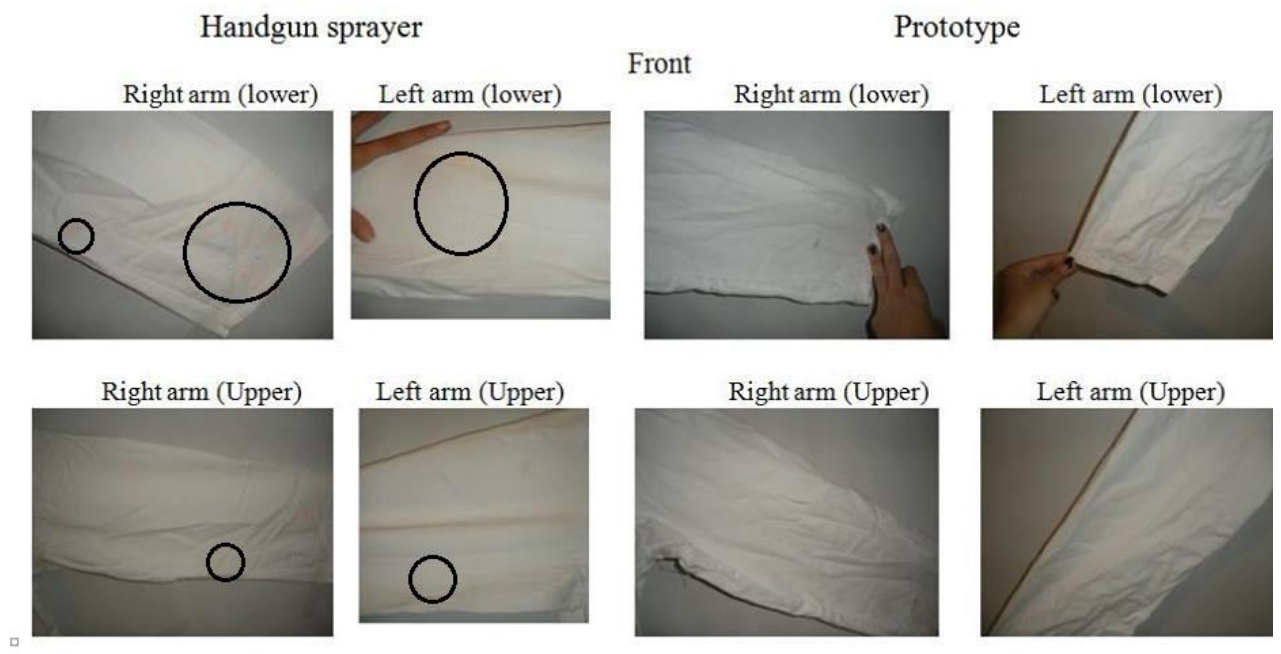

(a). Front view

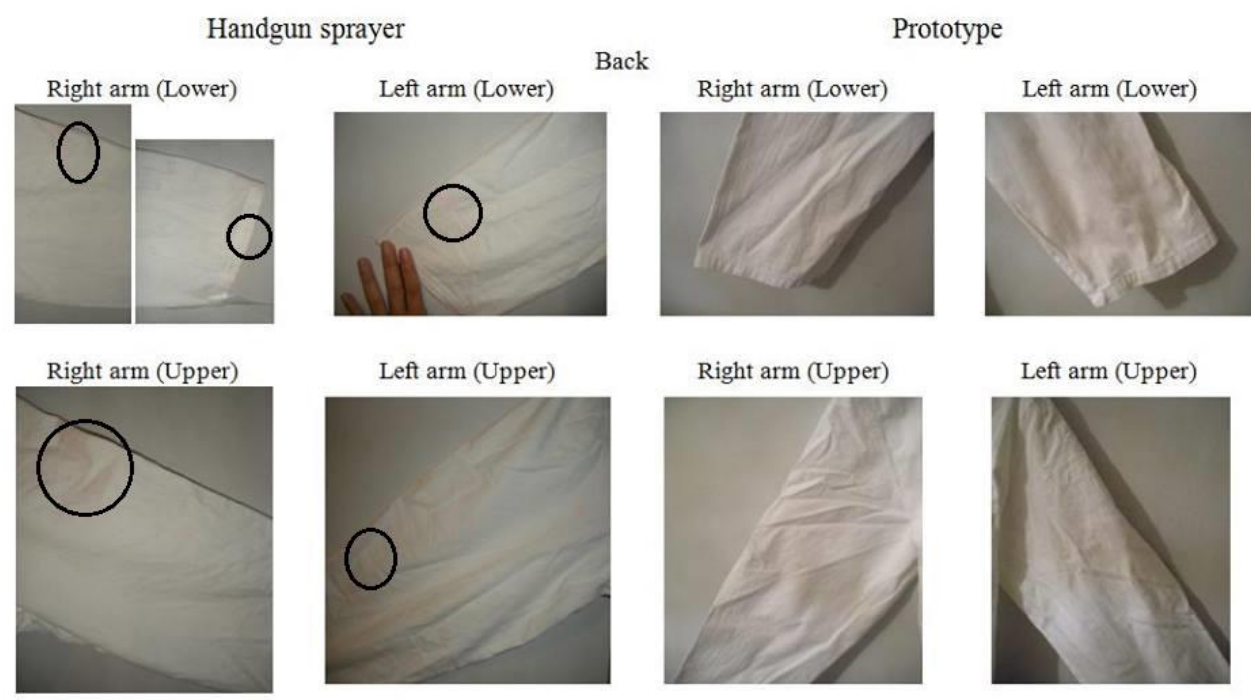

(b). Back view

Fig. (7). Right and left (upper and lower) arm for both hangun sprayer and prototype.

Hands were the most frequently contaminated, and the back had the highest body segment scores. Fig. (8) displays contaminated glove area (front and back) at right and left hand for both prototype and handgun 
sprayer. Hands constitute an area of 5\% of the total area of the body, so contaminated gloves area can reflect some of pollution assessment especially when workers did not wear gloves. Even though, vertical boom sprayer prototype achieved a considerable freedom of pollution problem, but it seemed that some pollution appeared on gloves. Contaminated area of gloves was 0.51 and $0.92 \%$ from back view for right and left hand respectively (hand palm) versus no pollution on front view (top surface of the hand) for both right and left hand. Continuous movement of right hand may be causes a reduction in pesticide exposure, at the same time opening and dealing with pesticide cans increased probability for pesticide exposure.
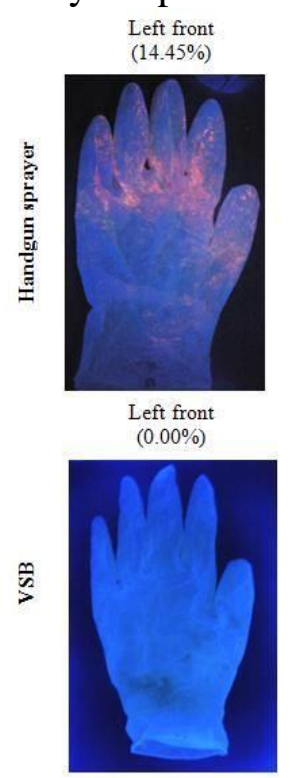

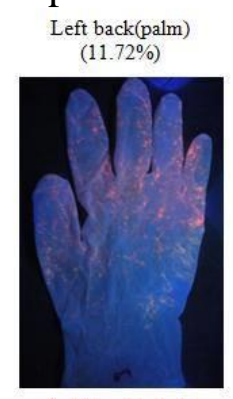

Left back(palm) $(0.92 \%)$

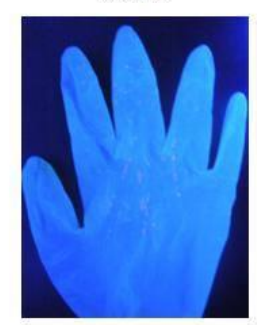

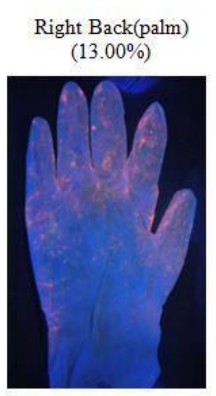

Right Back(palm) $(0.51 \%)$

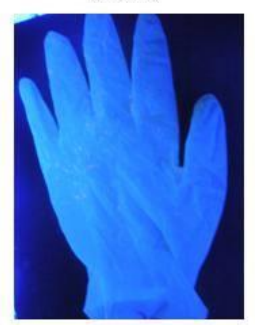

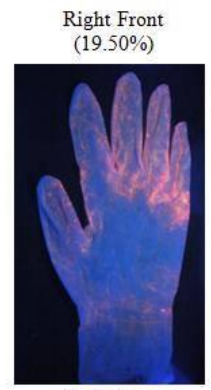

Right Front $(0.00 \%)$

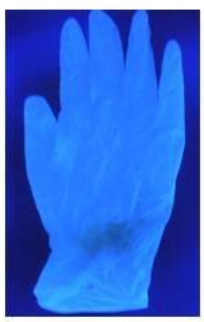

Fig. (8). Contaminated glove area (front and back) at right and left hand for both prototype and handgun sprayer.

In handgun application, the contaminated area of gloves was 13 and $11.72 \%$ for hand palm of right and left hand respectively against 19.50 and $14.45 \%$ for top surface. Definitely, right hand exposed to more pesticide effect than left hand, highest pesticide exposure was recorded at right hand surface, which worker left sprayer gun. Movement of left hand away from spray stream, that was used to operate a pump lever, made less values of pesticide exposure for both sides of hand. These results, almost compatible with the results of Machera et al., (2002) study and with Evans et al., (2001) studies of workplace protection, which 
suggested that the spread of contaminants inside protective clothing, including gloves, was commonplace and significant.

Similar trend can be noticed when exposure data had been analyzed for both worker legs. Right worker leg (thigh and shin) and left thigh (front and backside) were free from any exposure, left leg shin is exposed to some pollution $(0.42 \%$ at front and $0.82 \%$ at backside). Resulted data indicated that right leg for handgun application was less in pesticide exposure as shown in Fig. (9).

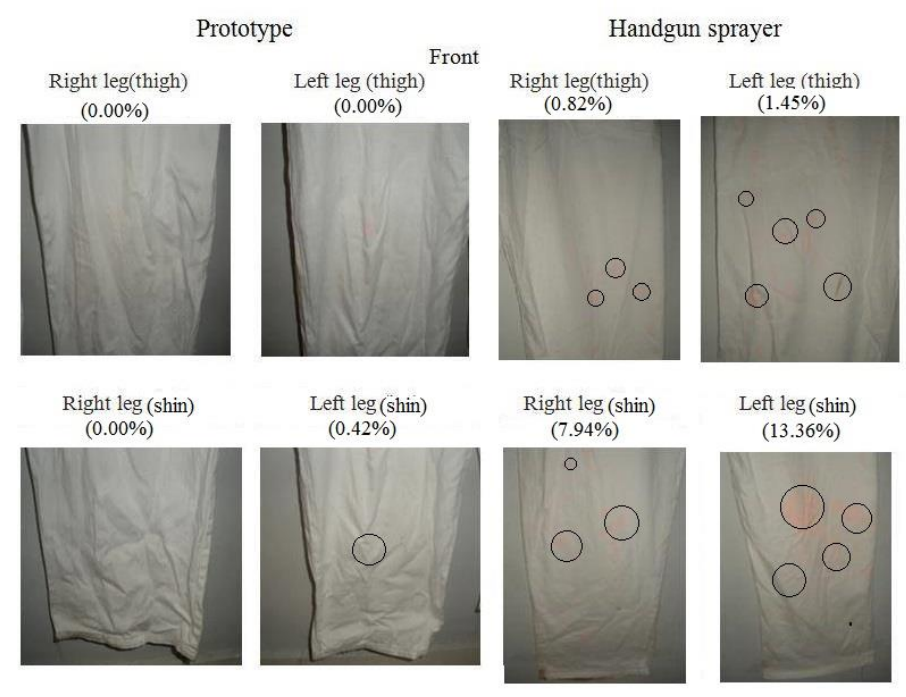

(a). Front view

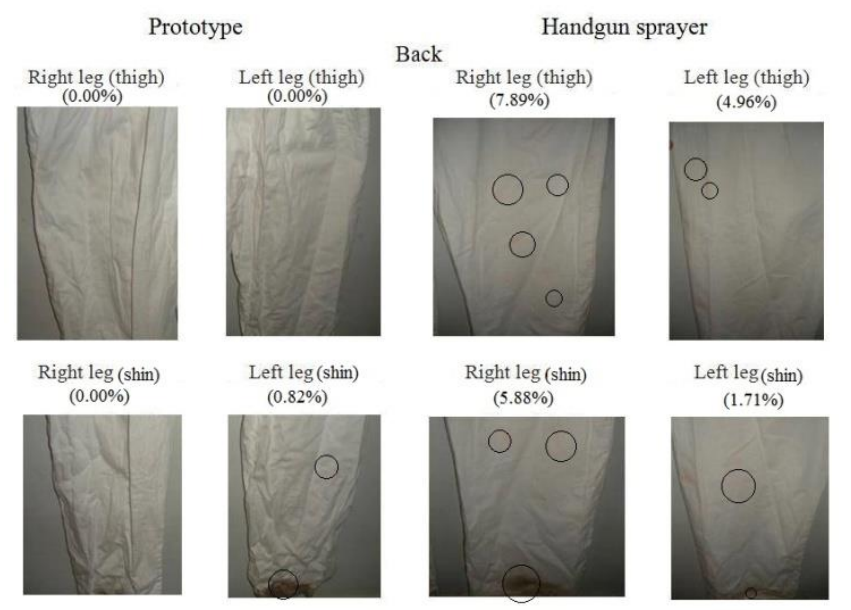

(b). Back view

Fig. (9). Right and left (upper and lower) leg (thigh and Shin) for both hangun sprayer and prototype. 
These results were consistent with the study conducted by Vidal et al., (2002), who showed that the highest exposure by pesticides during field applications in greenhouses occurred at lower legs and front thighs of the applicators.

More pesticide exposure was detected from handgun application ranged between no-exposure to $13.36 \%$ contaminated area. Highest exposure level was detected in both legs front side and concentrated at lower leg (shin). Regrettably, workers did not wear safety boots, though no data for feet area, which form about $7 \%$ of total body area, was taken.

\section{CONCLUSION}

Tested prototype maintained more working safety conditions when compared to handgun sprayer. 22 body segments ( $>90 \%$ of the total body surface area) scored for all workers, prototype is superior to handgun sprayer, contaminated area ratio of glasses was $0.28 \%$ - no pollution for the mask versus $8.11 \%$ and $9.15 \%$ respectively. Trunk, buttock, chest and shoulder contaminated area were 1.75, 1.60, 0.60 and $6.69 \%$ (front view) and were 1.79, 9.51, 0.73 and 0.00 at back view versus no pollution $(0.00 \%)$ in all previous cases of prototype. No pollution in any area of worker's arms compared to polluted area ranged between 0.00 and $8.17 \%$ for handgun sprayer. Contaminated area of gloves (5\% of total body area) ranged between 0.00 and $0.92 \%$ versus $11.72 \%-19.50 \%$ for handgun sprayer. worker legs exposed to some pollution $(0.42 \%$ and $0.82 \%)$ against more detected exposure extended to $13.36 \%$ for handgun sprayer Regrettably, workers did not wear safety boots, though no data for feet area, which form about $7 \%$ of total body area, was taken.

\section{REFERENCES:}

Aragón, A., L. E. Blanco, A. Funez, C. Ruepert, C. Lidén, G. Nise and C. Wesseling. (2006). Assessment of dermal pesticide exposure with fluorescent tracer: a modification of a visual scoring system for developing countries. British Occupational Hygiene Society. The Annuals of occupational hygiene. Vol., 50(1):75-83. Oxford University Press. 
Archibald B.A., K. R. Solomon and G. R. Stephenson GR. (1995). Estimation of pesticide exposure to greenhouse applicators using video imaging and other assessment techniques. American Industrial Hygiene Association Journal;56(3):226-235.

Barber, J.A.S., C.S. Parkin. (2003). Fluorescent tracer techniques for measuring the quantity of pesticide deposited to soil following soil application. Crop Prot. 22: 14-21.

Boeniger, M. F. (2003). The significance of skin exposure. Annotated Occupational Hygiene. 47(8):591-603.

Bozdogan, N. Y. and A. M. Bozdogan. (2009). Assessment of dermal bystander exposure in pesticide applications using different. Journal of Food, Agriculture and Environment. Vol.7 (2): 678-682.

Braekman, P. and B. Sonck. (2008). A review of the current spray applications techniques in various ornamental plant production systems in Flanders, Belgium. International Advances in Pesticide Application, Robinson College, Cambridge, UK, 9-11.pp: 303-308.

Cherrie, J. W., D. H. Brouwer, M. Roff, R. Vermeulen and H.Kromhout, H. (2000). Use of qualitative and quantitative Fluorescence techniques to assess dermal exposure. British Occupational Hygiene Society. The Annuals of occupational hygiene. Vol., 44(7): :519-522. Elsevier Science Ltd.

Chester, G. (1993). Evaluation of agricultural worker exposure to, and absorption of, pesticides. Annotated Occupational Hygiene. 37(5):509-523.

Durham W.F. and H. R. Wolfe. (1962). Measurement of the exposure of workers to pesticides. World Health Organization Bulletin. 26:7591. 
Evans, P.G., J. J. McAlinden and P. Griffin P. ( 2001). Personal protective equipment and dermal exposure. Journal Applied occupational and Environmental Hygiene. Vol. 16 (2) :334-337.

Fenske, R. A. (1993). Dermal exposure assessment techniques. Annotated Occupational Hygiene. 37(6):687-706.

Fenske, R. A., L. Chensheng, C. L. ynthia, J. H. Shirai and J. C. Kissel. (2005). Biologic monitoring to characterize organophosphorus pesticide exposure among children and workers: An analysis of recent studies in Washington State. Environmental Health Perspectives, 113(11), 1651-1657.

Fishel, F. M. (2011). Exposing pesticide exposure using fluorescent tracer.The Agronomy Department, Florida Cooperative Extension Service, Institute of Food and Agricultural Sciences, University of Florida. http://edis.ifas.ufl.edu.

Fritz, B. K., W. C. Hoffmann and P. Jank. (2011). A fluorescent tracer method for evaluating spray transport and fate of field and laboratory spray applications. Journal of ASTM International, 8(3), Paper ID JAI103619. Available online at www.astm.org

Giannandrea, F., L. Settimi and I. F. Talamanca, (2008). The use of personal protective equipment in pregnant greenhouse workers. Society of Occupational Medicine. Oxford University Press, (England), Vol. 58 (1): 52-57.

Machera, K. , M. Goumenou, E. Kapetanakis, A. Kalamarakis and R. C. Glass. (2003). Determination of potential dermal and inhalation operator exposure to malathion in greenhouses with the whole body dosimetry method. The Annual of Occupational Hygiene. Vol. 47 (1) : 61-70.

Machera, K., E. Kapetanakis, A. Charistou, E. Goumenaki and R. C. Glass. (2002). Evaluation of potential dermal exposure of pesticide spray operators in greenhouses by use of visible tracers. Journal of 
Environmental Science and Health, Part B, Pesticide, Food contaminated and agricultural wastes. 37:113-121.

MacIntyre-Allen, J. K., J. H. Tolman, C. D. Scott-Dupree and C. R. Harris. (2007). Confirmation by fluorescent tracer of coverage of onion leaves for control of onion thrips using selected nozzles, surfactants and spray volumes. Crop Protection. 26(11), 16251633.

Nuyttens, D., P. Braekman, S.Windey and B.Sonck. (2009). Potential dermal pesticide exposure affectedby greenhouse spray application technique. Pest Manag Sci. Vol. 65: 781-790.

OSHA. (2003). Occupational Safety and Health Administration. 200 Constitution Ave., NW, Washington, DC. 20210. www.OSHA.gov

Schleier, J. J., C. Preftakes, and R. K. D Peterson. (2010). The effect of fluorescent tracers on droplet spectrum, viscosity, and density of pesticide formulations. Journal of environmental science and health. Part. B, Pesticides, food contaminants, and agricultural wastes, 45(7), 621-625.

Soutar, A., S. Semple, R. J. Aitken and A. Robertson. (2000). Use of patches and whole body sampling for the assessments of dermal exposure. Annuals of Occupational Hygiene. Vol., 44 (7) :511-518 (2000).

Vidal, J. L. M., F. J. E.Gonzalez, A. G. Frenich, M. M. Galera, P. A. Aguilera and El. Carrique. (2002). Assessment of relevant factors and relationships concerning human dermal exposure to pesticides in greenhouse applications. Pest Manag Sci. Vol.: 58:784-790.

Wendel de Joode, B. V., R Vermeulen, J. J. van Hemmen, W. Fransman and H. Kromhout. (2005). Accuracy of a semiquantitative method for dermal exposure assessment (DREAM). Occupational and Environmental Medicine. Vol., 62(9): 623-632. 


\section{الملخص العربي}

\section{تقييم التعرض للمبيدات عن طريق الجلد داخل البيوت البلاستيكية باستخدام طريقة التتبع بلمبات القلورسنت داخل}

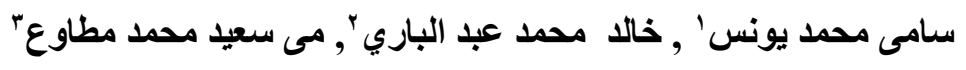

الهدف الرئيسي للعمل البحثى الحالى هو تقييم التعرض الجلدي للمبيدات اثثاء رشها داخل

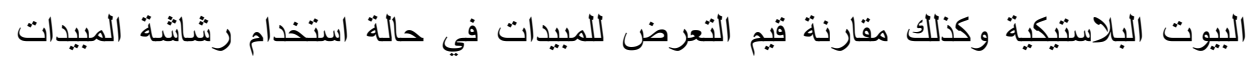

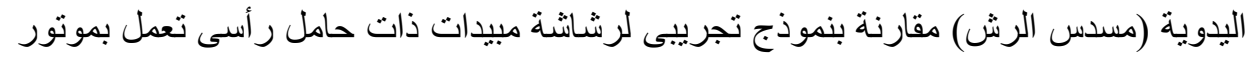

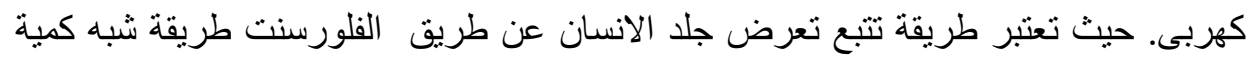

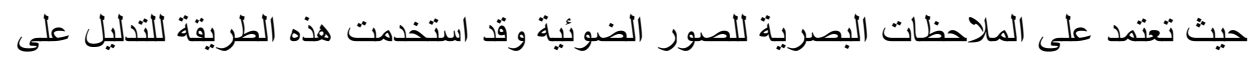

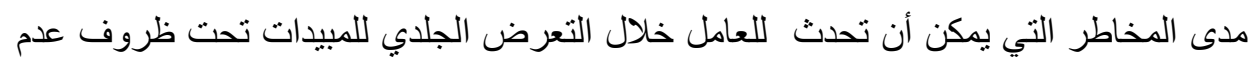

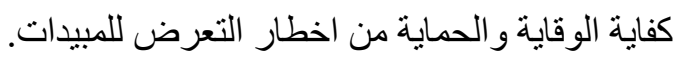

وقد اظهرت النتائج تفوق النموذج التجريبى للرشاثة ذات الحامل الرأسى في كل الحالات

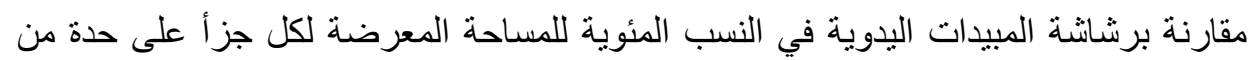

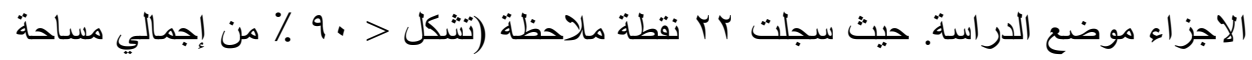

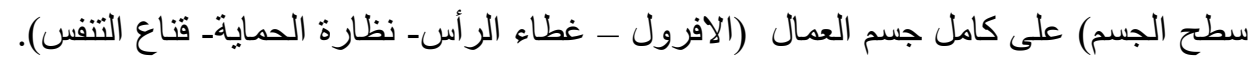

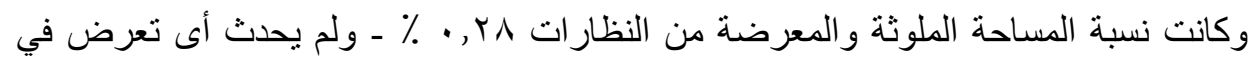

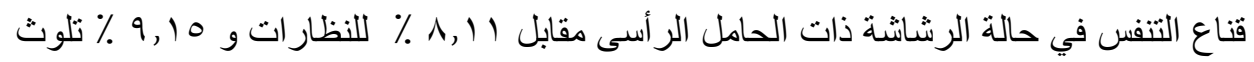

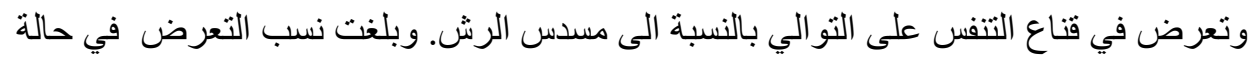

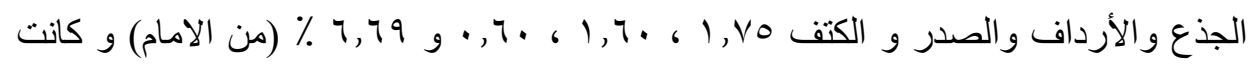

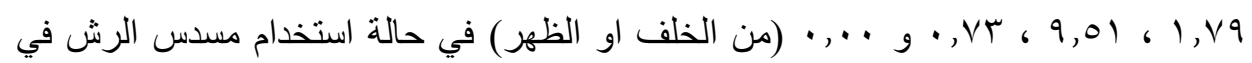

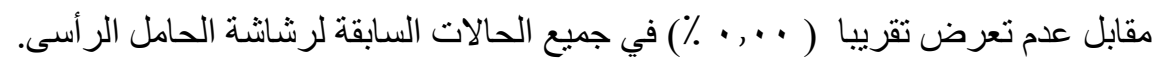
لم يحدث اى تعرض للمبيدات في منطقة الاذرع لجميع العمال في حالة الرشاشة ذات الحامل الر أسىى

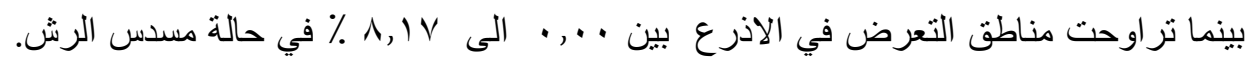

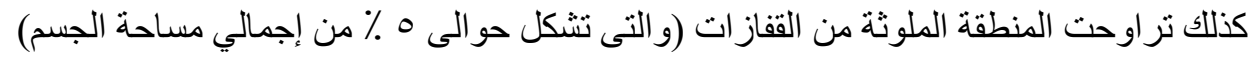

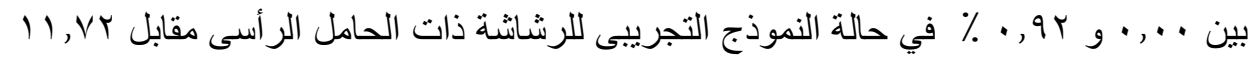

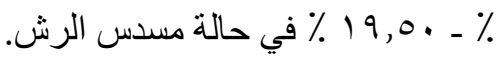

'أستاذ ـ قسم الهندسة الزراعية ـ كلية الزراعةـ جامعة القاهرة.

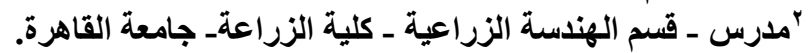
"طالبة ماجيستير-قسم الهندسة الزراعية ـ كلية الزراعة الزعة جامعة القاهرة. 


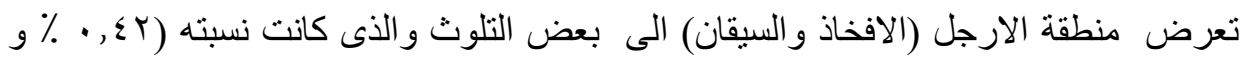

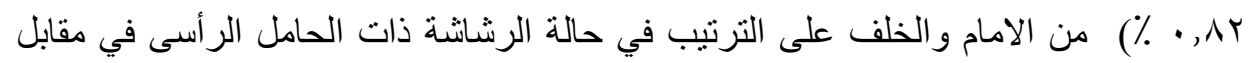

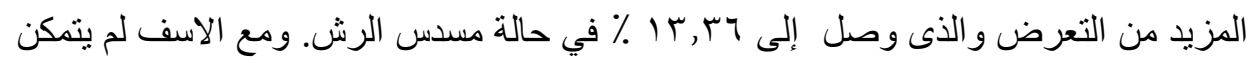

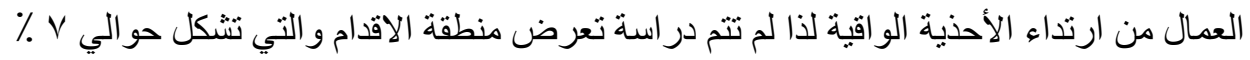

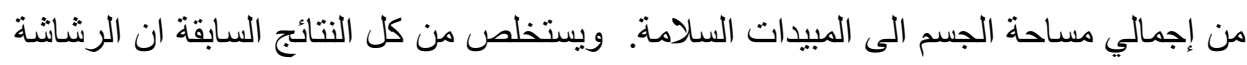

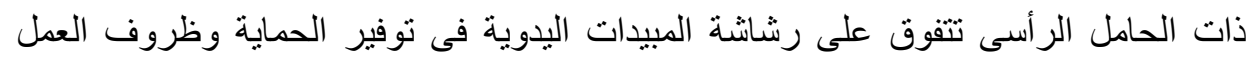

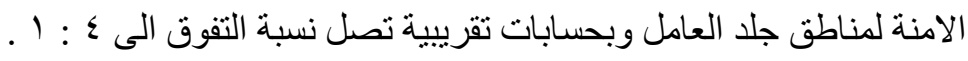
الكلمات الدالة: مبيدات ـ التعرض عن طريق الجلد ـ تقييم - صوبة ـ سلامة ـ بيئة ـ التتبع بالفلورسنت - ترسيب الرذاذـ استنشاقـ معدات و اقية. 